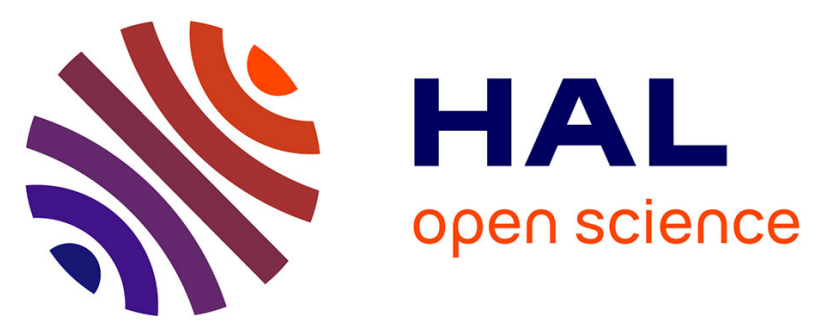

\title{
Modeling partial nitrification and denitrification in a hybrid biofilm reactor: calibration by retention time distribution and respirometric tests
}

Ming Zeng, Audrey Soric, Nicolas Roche

\section{- To cite this version:}

Ming Zeng, Audrey Soric, Nicolas Roche. Modeling partial nitrification and denitrification in a hybrid biofilm reactor: calibration by retention time distribution and respirometric tests. Environmental Science and Pollution Research, 2014, 22 (17), pp.nicolas.roche. 10.1007/s11356-014-3667-0 . hal01086582

\section{HAL Id: hal-01086582 \\ https://hal.science/hal-01086582}

Submitted on 3 May 2019

HAL is a multi-disciplinary open access archive for the deposit and dissemination of scientific research documents, whether they are published or not. The documents may come from teaching and research institutions in France or abroad, or from public or private research centers.
L'archive ouverte pluridisciplinaire HAL, est destinée au dépôt et à la diffusion de documents scientifiques de niveau recherche, publiés ou non, émanant des établissements d'enseignement et de recherche français ou étrangers, des laboratoires publics ou privés. 


\section{Modeling partial nitrification and}

denitrification in a hybrid biofilm reactor: calibration by retention time distribution and respirometric tests

\section{Ming Zeng, Audrey Soric \& Nicolas Roche}

Environmental Science and Pollution Research

ISSN 0944-1344

Environ Sci Pollut Res

DOI 10.1007/s11356-014-3667-0

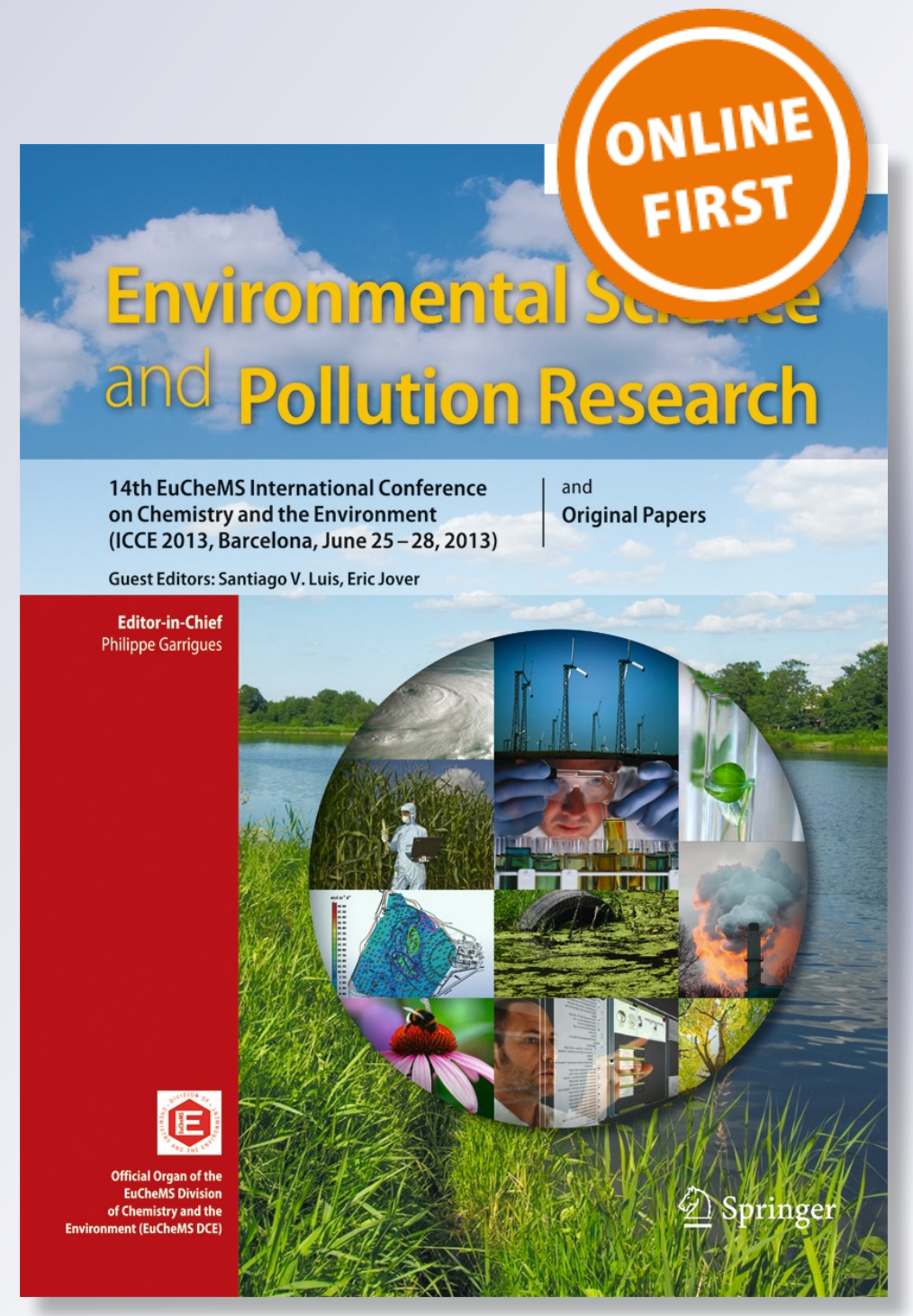

囪 Springer 
Your article is protected by copyright and all rights are held exclusively by SpringerVerlag Berlin Heidelberg. This e-offprint is for personal use only and shall not be selfarchived in electronic repositories. If you wish to self-archive your article, please use the accepted manuscript version for posting on your own website. You may further deposit the accepted manuscript version in any repository, provided it is only made publicly available 12 months after official publication or later and provided acknowledgement is given to the original source of publication and a link is inserted to the published article on Springer's website. The link must be accompanied by the following text: "The final publication is available at link.springer.com". 


\title{
Modeling partial nitrification and denitrification in a hybrid biofilm reactor: calibration by retention time distribution and respirometric tests
}

\author{
Ming Zeng • Audrey Soric • Nicolas Roche
}

Received: 28 April 2014/Accepted: 26 September 2014

(C) Springer-Verlag Berlin Heidelberg 2014

\begin{abstract}
In this study, partial nitrification coupled with denitrification is modeled in a hybrid biofilm reactor with different hydraulic saturation conditions. The activated sludge model with two-step nitrification is implemented in GPS-X software. Hydrodynamic modeling by retention time distribution analysis and biokinetic measurement by respirometric tests are two significant parts of model calibration. By combining these two parts, partial nitrification in the aerobic part of the column is well simulated with a good agreement between experimental and modeled effluent concentrations of $\mathrm{NH}_{4}^{+}$ and $\mathrm{NO}_{2}{ }^{-}$. Particularly, fully hydraulic saturation condition contributes to the large hydraulic volume of $1.9 \mathrm{~L}$ and high produced $\mathrm{NO}_{2}^{-}$concentration around $40 \mathrm{mg} \mathrm{L}{ }^{-1}$. However, modeling denitrification still needs to be improved with more calibrated parameters. Furthermore, three alternatives are proposed for the optimization of reactor design and operation.
\end{abstract}

Keywords Hydrodynamic behavior · Ammonium-oxidizing bacteria $\cdot$ Respirometer $\cdot$ Engineering $\cdot$ GPS-X $\cdot$ Wastewater treatment

\section{Abbreviations}

A

Specific surface area of porous media (square meters per cubic meter)

Responsible editor: Gerald Thouand

Electronic supplementary material The online version of this article (doi:10.1007/s11356-014-3667-0) contains supplementary material, which is available to authorized users.

M. Zeng $\cdot$ A. Soric $\cdot$ N. Roche $(\triangle)$

Aix Marseille University, Centrale Marseille, CNRS, M2P2 UMR

7340, Europôle de l'Arbois, 13545 Aix en Provence, Cedex 4,

France

e-mail: nicolas.roche@univ-amu.fr
$b_{\mathrm{H}} \quad$ Decay (endogenous respiration) rate of heterotroph (per day)

$b_{\mathrm{A}} \quad$ Decay (endogenous respiration) rate of autotroph (per day)

$b_{\mathrm{AOB}} \quad$ Decay (endogenous respiration) rate of AOB (per day)

$b_{\mathrm{NOB}} \quad$ Decay (endogenous respiration) rate of NOB (per day)

$C(t) \quad$ Tracer concentration (grams per liter)

$E(t) \quad$ Retention time distribution (per minute)

$e_{\mathrm{v}} \quad$ Effective volume ratio (percent)

$f_{\mathrm{P}} \quad$ Fraction of inert material in biomass (-)

$K_{\text {S.H }} \quad$ Substrate constant affinity for heterotroph (milligrams per liter)

$K_{\text {NH.A }} \quad$ Substrate constant affinity for autotroph (milligrams per liter)

$K_{\mathrm{NH} . \mathrm{AOB}} \quad$ Substrate constant affinity for AOB (milligrams per liter)

$K_{\mathrm{NO} 2 \text {.NOB }}$ Substrate constant affinity for NOB (milligrams per liter)

$N \quad$ Number of stirred tanks (-)

$Q(t) \quad$ Water flow rate at the outlet (liters per minute)

$R \quad$ Tracer recovery (percent)

$r \quad$ Respiration rate (milligrams per liter per hour)

$t_{\text {actual }} \quad$ Actual hydraulic retention time (minutes)

$t_{\text {im }} \quad$ Exchanging time between mobile and immobile volume (minutes)

Time of plug flow (minutes)

Hydraulic volume (liters)

Biomass concentration (milligrams per liter)

Yield rate of autotroph (grams COD per gram $\mathrm{N}$ )

Yield rate of AOB (grams COD per gram $\mathrm{N}$ )

Yield rate of heterotroph (grams COD per gram COD)

$Y_{\mathrm{NOB}} \quad$ Yield rate of NOB (grams COD per gram N)

$\delta \quad$ Mean square sensitivity measure (-) 


$\begin{array}{ll}\eta & \text { Anoxic growth constant of heterotroph }(-) \\ \theta & \text { Nominal hydraulic retention time }(-) \\ \mu_{\text {A.max }} & \begin{array}{l}\text { Maximum specific growth rate of autotroph (per } \\ \text { day) }\end{array} \\ \mu_{\text {AOB.max }} & \begin{array}{l}\text { Maximum specific growth rate of AOB (per day) } \\ \mu_{\text {H.max }}\end{array} \\ \begin{array}{l}\text { Maximum specific growth rate of heterotroph } \\ \text { (per day) }\end{array} \\ \mu_{\text {NOB.max }} & \begin{array}{l}\text { Maximum specific growth rate of NOB (per day) } \\ \tau\end{array} \\ \text { Theoretical hydraulic retention time (minutes) }\end{array}$

\section{Introduction}

Over several decades, partial nitrification is an economic technique in highly efficient compact bioreactors to produce nitrite instead of nitrate by inhibiting nitrite-oxidizing bacteria (NOB). Nowadays, many successful cases of partial nitrification reactors reveal their advantages and necessity in removing nitrogen compounds, especially when they are coupled with denitrification and anaerobic ammonium oxidizing (anammox). A single reactor system of high ammonium removal over nitrite (SHARON) has been developed to accelerate partial nitrification allowing higher $\mathrm{NH}_{4}^{+}$loading rate and less cost of aeration compared with the traditional complete nitrification reactor. For example, Gali et al. (2007) found that SHARON was more stable than sequencing batch reactor (SBR) when the influent ammonium concentration fluctuated, and SHARON was also slightly cheaper. Furthermore, partial nitrification coupled with denitrification needs less organic matter (reduced by $40 \%$ ), oxygen (reduced by $25 \%$ ), and even half of $\mathrm{HCO}_{3}{ }^{-}$added. A full-scale plant $\left(1,500 \mathrm{~m}^{3}\right)$ combining SHARON reactor with denitrification has been installed to treat ammonium-rich wastewater resulting in cost-efficient industrial processes (Hellinga et al. 1999).

Mathematical modeling is not only used to understand mechanisms of pollutant removal, but also to enhance the efficiency of pollutant removal by optimizing the design of the bioreactor. Although default values of various model parameters are usually adopted, they are certainly not able to represent specific processes in all conditions. Thus, it has been well accepted that the calibration processes ought to be carried out in order to realize the accurate simulated results in different types of bioreactors. So far, Petersen et al. (2002) and Vanrolleghem et al. (2003) have described protocols of activated sludge model (ASM) calibration in detail. There are generally three principal aspects: hydraulic, setting, and biological characterizations. Settling performance usually needs to be considered in wastewater treatment plants (WWTPs) with clarifiers. Since this study mainly focuses on pilot-scale bioreactors, two other items are thus discussed except setting calibration.
On one hand, hydrodynamic behavior is a critical part of model calibration, which has been found to determine the prediction of pollutant elimination and sampling strategies in WWTPs (Majewsky et al. 2011). The analysis of retention time distribution (RTD) is an efficient and reliable approach of hydrodynamic study in trickling filter, biological aerated filter, as well as fluidized bed bioreactor (Sánchez et al. 2005; Vanrolleghem et al. 2003; Zeng et al. 2013). Specifically, breakthrough curves (BTCs) are firstly obtained by monitoring the tracer concentration at the outlet as a function of time. Furthermore, hydraulic parameters such as number of stirred tanks and actual hydraulic volume can be known by fitting BTCs with the appropriate hydraulic models.

On the other hand, a great number of biokinetics and stoichiometries need to be measured by either offline or online respirometric tests to conduct the proposed biological calibration. Since series of ASM are developed and continuously improved, parameters in Monod equations of various biological processes are found to be in a wide range of values (Henze et al. 1987, 2000). Over several decades, respirometric test is mainly proposed to measure these parameters in suspended sludge reactors, while traditional respirometric reactor is not suitable for biofilm study due to the potential destruction of biofilm structure by the shear force of aeration. Nowadays, a novel respirometric reactor special for biofilm should be used. In addition, more information like substrate concentrations other than respiration rate gives more precise and reliable biokinetics.

Thus, a comprehensive biofilm model based on ASM with two-step nitrification and biofilm diffusion coefficients was developed in the environment of GPS-X software. The proposed model adopted calibrated hydraulic parameters as well as calibrated biokinetics to simulate processes of partial nitrification coupled with denitrification. Changing hydraulic saturation condition in the reactor helped to emphasize the importance of hydrodynamic calibration. Practically, improvements of reactor design and operation were proposed to enhance the efficiency of partial nitrification.

\section{Material and methods}

Reactor and sampling

\section{Setup and operation}

Plastic rings (Kaldnes K $1{ }^{\circledR}$ with porosity of $80 \%$ and specific surface area of $800 \mathrm{~m}^{2} / \mathrm{m}^{3}$ ) coated with inoculated heterotrophic and autotrophic biofilms from SBR were filled in two identical columns. For starting-up nitritation systems, SBR was reported to be an attractive alternative due to a short period of operation required (Torà et al. 2013). Figure 1 shows the diagram of SBR and configuration of pilot column. After 
1 month, carriers were transferred into the column that was separated by an air diffuser to create an aerated part with bed volume of $4.7 \mathrm{~L}$ and an anoxic part with bed volume of $1.6 \mathrm{~L}$. The air flow rate was set as $1 \mathrm{~L} \mathrm{~min}^{-1}$.

The height of the outlet tube determined the hydraulic saturation condition in the biofilters. As presented in Fig. 1, when the height of tube stayed $20 \mathrm{~cm}$, the aerated part performed like an unsaturated trickling filter. Then the height of tube, being $40 \mathrm{~cm}$, produced a half-saturated condition. Once the height of tube arrived at $100 \mathrm{~cm}$, fully saturated condition was maintained in the aerobic part.

Synthetic wastewater was prepared by adding sucrose for the development of heterotroph and $\mathrm{NH}_{4} \mathrm{Cl}$ for autotroph. The ratio of chemical oxygen demand (COD) by $\mathrm{N}$ was $2: 1$ with high and low $\mathrm{NH}_{4}^{+}-\mathrm{N}$ concentrations, 150 and $65 \mathrm{mg} \mathrm{L}^{-1}$, respectively. Besides, synthetic wastewater contained 0.7 to $1.0 \mathrm{~g} \mathrm{~L}^{-1}$ of $\mathrm{NaHCO}_{3}, 30 \mathrm{mg} \mathrm{L}^{-1}$ of $\mathrm{KH}_{2} \mathrm{PO}_{3}, 20 \mathrm{mg} \mathrm{L}^{-1}$ of $\mathrm{CaCl}_{2}$, and $20 \mathrm{mg} \mathrm{L}^{-1}$ of $\mathrm{MgSO}_{4}$. Water was fed in a continuous mode with a peristaltic pump (Masterflex ${ }^{\circledR} \mathrm{L} / \mathrm{S}^{\mathrm{TM}}$ ) at a flow rate of $0.5 \mathrm{~L} \mathrm{~h}^{-1}$ and velocity of $1.5 \mathrm{~m} \mathrm{day}^{-1}$. The experiment was operated at room temperature $\left(15\right.$ to $\left.20^{\circ} \mathrm{C}\right)$ and dissolved oxygen (DO) in the aerobic part of column stayed around $4 \mathrm{mg} \mathrm{L}^{-1}$.

The experimental period lasted 3 months with two operational factors changing: influent $\mathrm{NH}_{4}{ }^{+}-\mathrm{N}$ concentrations and hydraulic saturation conditions. In the first 4 weeks, at a low influent $\mathrm{NH}_{4}{ }^{+}-\mathrm{N}$ concentration of $65 \mathrm{mg} \mathrm{L}^{-1}$, two parallel columns were separately maintained in unsaturated and halfsaturated condition. In the next 4 weeks, one column in halfsaturated condition was switched to fully saturated condition. Afterwards, the influent $\mathrm{NH}_{4}{ }^{+}-\mathrm{N}$ concentration was increased to $150 \mathrm{mg} \mathrm{L}^{-1}$ for the next 4 weeks.

\section{Physicochemical analysis}

Effluents were sampled each day to analyze temperature, DO by a DO meter (Hach HQ10), and $\mathrm{pH}$ by a $\mathrm{pH}$ meter (Hanna 210). Concentrations of nitrate and ammonium were measured by a $\mathrm{NH}_{4}{ }^{+}$and $\mathrm{NO}_{3}{ }^{-}$probe (AN-ISE SC, Hach Lange). Then samples were filtered through a glass membrane of $1.0 \mu \mathrm{m}$ pore size and $25 \mathrm{~mm}$ diameter (Millipore), and frozen before measuring the nitrite that was conducted by a kit of $\mathrm{NO}_{2}^{-}\left(0-150 \mathrm{mg} \mathrm{L}^{-1} \mathrm{NO}_{2}^{-}-\mathrm{N}\right.$, Hanna Instrument).

\section{RTD analysis}

The 10 to $30 \mathrm{~mL}$ of concentrated $\mathrm{NaCl}$ solution $\left(200\right.$ g. $\left.\mathrm{L}^{-1}\right)$ was injected at the inlet of reactor in a pulse way, which contributed to much higher electronic conductivity (EC) than that of synthetic wastewater. Electronic conductivity of the effluent was recorded each second by an EC meter (WTW 3310). A calibration curve was carried out by measuring EC values of standard $\mathrm{NaCl}$ solutions (concentration from 0 to $40 \mathrm{~g} \mathrm{~L}^{-1}$ ).

Breakthrough curves of $E(t)$ were obtained by Eq. 1:

$\mathrm{E}(\mathrm{t})=\frac{\mathrm{C}(\mathrm{t}) \mathrm{Q}(\mathrm{t})}{\mathrm{M}_{\text {tracer }}}$

where $M_{\text {tracer }}$ is the total mass of tracer injected (grams), $C(t)$ is tracer concentration (grams per liter), and $Q(t)$ is water flow rate at the outlet (liters per minute).

The actual hydraulic retention time $\left(t_{\text {actual }}\right)$ and actual hydraulic volume $\left(V_{\text {actual }}\right)$ was calculated by the first-order moment analysis in Eqs. 2 and 3:

$\mathrm{t}_{\text {actual }}=\int_{0}^{\infty} \mathrm{E}(\mathrm{t}) \mathrm{tdt}$

$\mathrm{V}_{\mathrm{actual}}=\mathrm{Q} \cdot \mathrm{t}_{\mathrm{actual}}$

The theoretical retention time $(\tau)$ was calculated by Eq. 4:

$\tau=\frac{\mathrm{V}_{\text {void }}}{\mathrm{Q}}$

where $V_{\text {void }}$ is total void volume in filters.

The ratio of effective volume $\left(e_{\mathrm{v}}\right)$ was introduced to describe the hydrodynamic behavior in Eq. 5:

$\mathrm{e}_{\mathrm{v}}=\frac{\mathrm{t}_{\mathrm{actual}}}{\tau}=\frac{\mathrm{V}_{\text {actual }}}{\mathrm{V}_{\text {void }}}$

DTS Pro. software (Version 4.20, France) offers a userfriendly interface to implement hydraulic models. A model of Tanks-In-Series (TIS) with exchanged zones notably permits the representation of BTCs with a long tail. This model is composed by the mobile volume $\left(V_{\mathrm{m}}\right)$ accessible for the effluent outside the biofilm and the immobile volume $\left(V_{\mathrm{im}}\right)$ of biomass exchanging water with $V_{\mathrm{m}}$ in a certain time $\left(t_{\mathrm{im}}\right)$. In addition, the model of plug flow should be added if there is a sharp increase of BTCs peak. The sum of plug flow volume, mobile volume, and immobile volume is the actual hydraulic volume that will be entered into the model of biodegradation. 
Fig. 1 Sketch of pilot-scale hybrid column and illustration of changing hydraulic conditions in aerobic part

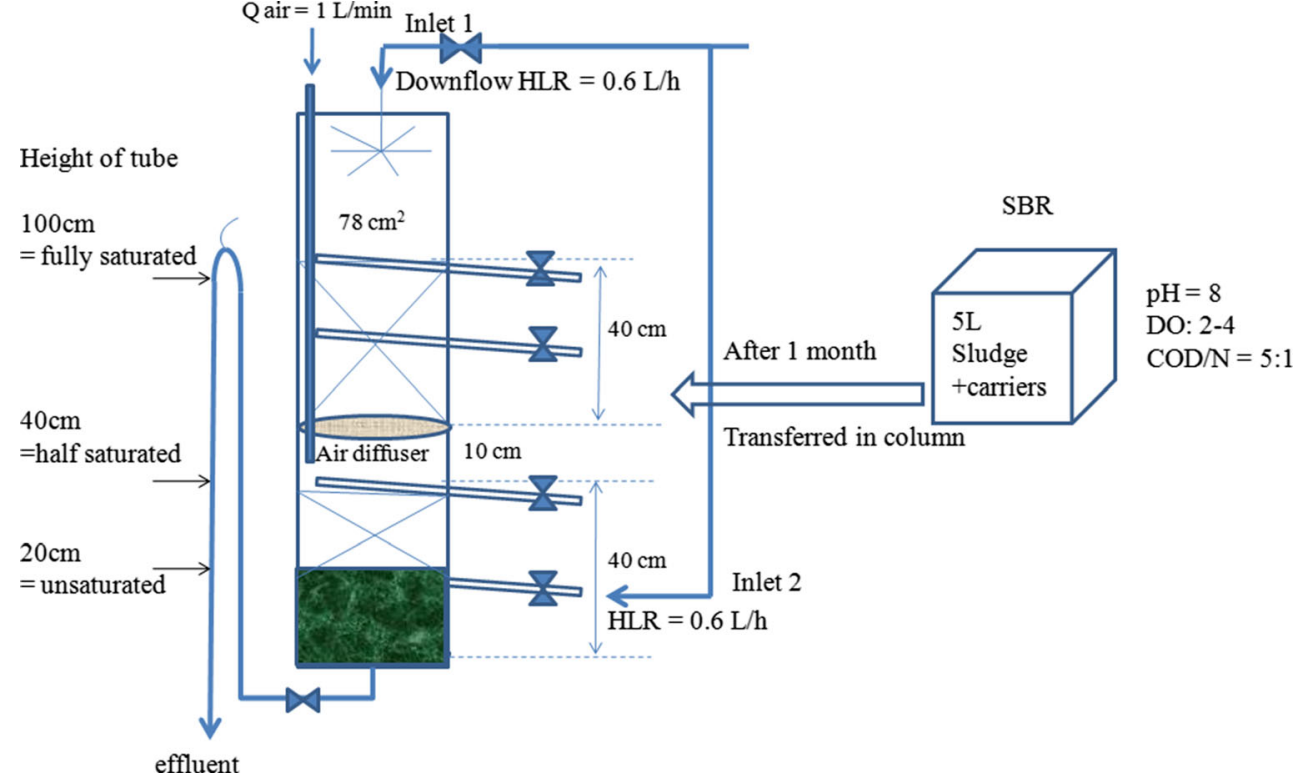

\section{Respirometric test}

A respirometer (BM-Evo respirometer, Equipements Scientifiques) was used to carry out respirometric tests for attached biofilm. The oxygen consumption is related to the aerobic activity of the biomass, including exogenous growth of heterotrophic bacteria, exogenous growth of autotrophic bacteria (classified to ammoniumoxidizing bacteria (AOB) and $\mathrm{NOB}$ ), and their endogenous respirations.

DO concentration ranged between 4 and $5 \mathrm{mg} \mathrm{L}^{-1}$ in the reactor by switching on/off of the aeration valve. A great number of biokinetics and stoichiometries can be calculated from the curve of the respiration rate. Endogenous decay rate (b) was determined by monitoring the decrease of endogenous respiration rate for an enough long time (1 day in our study) in Eqs. 6 and 7.

$\mathrm{b}=\frac{\mathrm{b}^{\prime}}{1-\mathrm{Y}\left(1-\mathrm{f}_{\mathrm{p}}\right)}$

$\ln \left(\frac{\operatorname{rend}(0)}{\operatorname{rend}(t)}\right)=\mathrm{b}^{\prime} . \mathrm{t}$

where $b^{\prime}$ is the observed decay rate (per day), $\mathrm{Y}$ is the yield rate, $f \mathrm{p}$ is the inert fraction of particulate organic matter that is assumed to be default value of 0.08 in this study, $r_{\text {end }}$ is the endogenous respiration rate (milligrams per liter per hour), and $t$ is the time (days).
Different from decay rate, maximum growth rate $\left(\mu_{\max }\right)$ is calculated by the increase of exogenous respiration rate $\left(r_{\text {ex }}\right)$ in Eq. 8.

$\ln \left(\frac{\operatorname{rex}(\mathrm{t})}{\operatorname{rex}(0)}\right)=\left(\mu_{\max }-\mathrm{b}\right) \mathrm{t}$

The respirometer was coupled with the probe of ammonium and nitrate to continuously measure $\mathrm{NH}_{4}{ }^{+}$and $\mathrm{NO}_{3}{ }^{-}$by connecting a peristaltic pump of respirometer to a small tank of $230 \mathrm{~mL}$. Therefore, online analysis of respiration rate, $\mathrm{NH}_{4}{ }^{+}$and $\mathrm{NO}_{3}{ }^{-}$allowed calculating yield rates $(Y)$ by Eqs. 9 to 11 for heterotroph, AOB, and NOB, respectively.

$\mathrm{Y}_{\mathrm{H}}=\frac{\mathrm{S}_{\mathrm{s}}-\int \mathrm{r}_{\mathrm{ex}}(\mathrm{t}) \mathrm{dt}}{\mathrm{S}_{\mathrm{s}}}$

$\mathrm{Y}_{\mathrm{AOB}}=\frac{3.43 \mathrm{~S}_{\mathrm{NH}}-\int \mathrm{r}_{\mathrm{ex}}(t) \mathrm{dt}}{S_{\mathrm{NH}}}$

$\mathrm{Y}_{\mathrm{NOB}}=\frac{1.14 S_{\mathrm{NO}^{-}} \int r_{\mathrm{ex}}(\mathrm{t}) d t}{S_{\mathrm{NO}^{-}}}$

where $S$ is the substrate concentration (milligrams per liter.)

In order to conduct a complete respirometric test, 0.5 to $1.0 \mathrm{~g} \mathrm{~L}^{-1} \mathrm{NaHCO}_{3}$ was firstly added to supply inorganic carbon for the nitrifier and neutral $\mathrm{pH}$ condition from 7 to 
8.5. In fact, after we put our biofilm samples into the respirometer, we added distilled water to make the endogenous condition. Then we found that $1 \mathrm{~h}$ was needed to wait for the stable condition, including temperature, endogenous respiration rate, and probe of $\mathrm{NH} 4$ and $\mathrm{NO} 3$ measurement. After a stable endogenous respiration was established, $30 \mathrm{mg} \mathrm{L}^{-1} \mathrm{~N}$ $\mathrm{NH}_{4} \mathrm{Cl}, 5 \mathrm{mg} \mathrm{L}^{-1}$ allylthiourea (ATU), and $50 \mathrm{mg} \mathrm{L}^{-1} \mathrm{COD}$ from sucrose were successively injected to study activity of autotroph and heterotroph. ATU is usually used to inhibit the activity of autotrophic bacteria. Each pulse injection was conducted after the previous process absolutely was finished, which was signified by the return of endogenous respiration.

\section{Biological modeling}

\section{Matrix of ASM with biofilm diffusion}

A library of "cn2lib" in GPS-X software (Hydromantis Inc. Canada) was chosen including two-step nitrification that is shown in Table A. 1. A slight change is that the endogenous respiration was assigned in the decay of biomass contributing to the oxygen consumption. The matrix consists of 14 variables and 15 biological processes whose rates are expressed by multi-Monod equations. Diffusion of soluble substrates and DO is one-dimensional in the biofilm thickness with default values of diffusion coefficient of substrates and DO (Table A. 1). Combining diffusion rate and Monod kinetic biodegradation of substrates helps to present mass balance equations of these variables (Huiliñir et al. 2010). The implementation of model was conducted automatically by the numerical solvers in software.

\section{Model validation}

The layout of model was composed by trickling filters, and parameters of $\mathrm{N}$ and $V_{\text {actual }}$ from hydraulic modeling were used to adjust the number of filters and the filter depth in the trickling filter component, respectively. Meanwhile, biokinetics and stoichiometries of different bacteria from respirometric tests were input to the biological parameters of model. The execution of model was under steady-state condition.

Three kinds of indicators were used to evaluate the agreement between experimental and modeled data. The Theil inequality coefficient (TIC) was suggested by Hvala et al. (2005) in Eq. 12:

$$
\mathrm{TIC}=\frac{\sqrt{\sum_{i}\left(y_{i}-y_{m, i}\right)^{2}}}{\sqrt{\sum_{i} y_{i}{ }^{2}}+\sqrt{\sum_{i} y^{2}{ }_{m, i}}}
$$

where $y_{i}$ is the experimental data, $y_{m, i}$ is the modeled data. The values of TIC below 0.3 imply a good agreement.

The modified index of agreement (MIA) was used as another estimator for a goodness of fit that is defined by Eq. 13 (Legates and McCabe 1999):

MIA $=1-\frac{\sum_{i}\left|y_{i}-y_{m, i}\right|}{\sum_{i}\left|y_{i}-y_{m, i}\right|+\sum_{i}\left|y_{i}-y_{i}\right|}$

where $\overline{y_{i}}$ is the average of the experimental data. The MIA varies between 0 and 1 , and higher values mean a better agreement between the modeled and experimental data.

The normal objective function (NOF) is the ratio of the root mean square error to the overall mean of the experimental data in Eq. 14 (Gikas et al. 2006):

$\mathrm{NOF}=\sqrt{\frac{\sum_{i}\left(y_{i}-y_{m, i}\right)^{2}}{N}} \frac{N}{\sum_{i} y_{i}}$

where $N$ is the total number of values. NOF equal to 0 means a perfect match between experimental and modeled data. However, when parameter is less than 1, then the theoretical method is still reliable and can be used with sufficient accuracy.

\section{Results and discussion}

Modeling hydrodynamic behavior

Referring to two inlets in the entire column (unsaturated aerobic part at the top and saturated anoxic part at the bottom), an integrated layout is shown in Fig. 2. Hydraulic model in aerobic zone is represented by the plug flow followed by TIS with exchanged zones, and model in anoxic zone is assumed to be described by the TIS. Two hydraulic saturation conditions in the aerobic part were compared: unsaturated and fully saturated. Experimental and fitted BTCs are presented in Fig. 2 with a good consistency, except for the end tail of BTCs, probably due to the tracer recovery less than $90 \%$ (Table 1). Although changing $\mathrm{NaCl}$ by another tracer like $\mathrm{Li}^{+}$ could give a high tracer recovery even in field-scale trickling filter due to its lower detection limit and inert characteristic for biology (Séguret et al. 2000), experimental BTCs in this study 


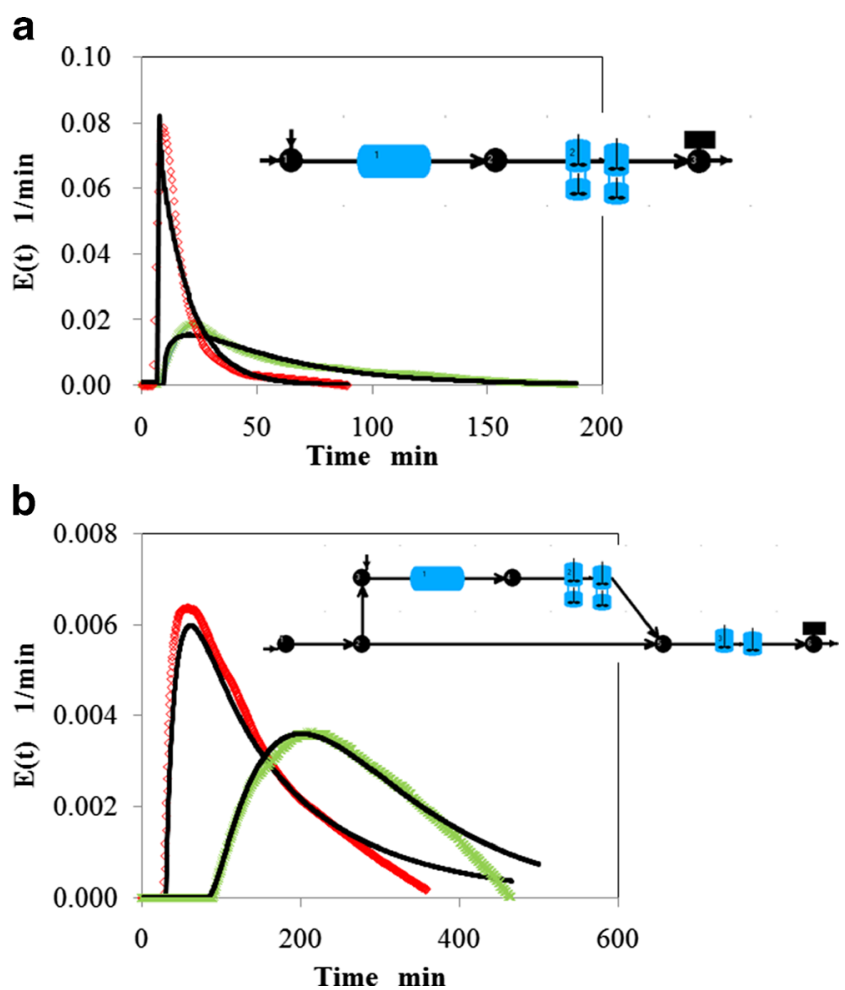

Fig. 2 Layout of the entire column and experimental and modeled BTCs after biofilm growth under different hydraulic saturation conditions; experimental data: unsaturated aerobic condition (open diamonds), saturated aerobic condition (multiplication symbol); modeled data (lines)

are thought to be generally well fitted by this integrated model.

The hydraulic parameters are summarized in Table 1. Compared with the unsaturated hydraulic condition, effective volume ratio in aerobic zone increased to $45 \%$ in fully saturated hydraulic condition. The integrated hydraulic model quantified the increase of actual hydraulic volume in aerobic zone that the volume for plug flow increased by $0.45 \mathrm{~L}$, and mobile volume and immobile volume increased by 0.11 and $0.20 \mathrm{~L}$, respectively. Furthermore, taking account into the area of bed surface, the depth of trickling filter bed in the layout of GPS-X software was assigned to be 15,20 , and $25 \mathrm{~cm}$ in unsaturated, half-saturated, and fully saturated hydraulic condition, respectively. $N$ was assigned to be the number of trickling filter in the layout. This approach bridges hydrodynamic results with the biodegradation model.
Calibration of biokinetics and stoichiometries

Calculating parameters of $\boldsymbol{b}, \boldsymbol{\mu}_{\max }$, and $\boldsymbol{Y}$

Figure $3 a$ and $b$ introduces the changing of respiration rate of heterotrophic biofilm after 1 day endogenous condition. During first day, the endogenous respiration rate stayed around $7.8 \mathrm{mg} \mathrm{L}^{-1} \mathrm{~h}^{-1}$, while a slow decreasing trend of endogenous respiration rate was observed after 1 day in Fig. 3a, which is caused by the decay of biomass. Then, in light of Eqs. 6 and 7 , the decay rate of heterotrophic biofilm arrived at 0.58 day $^{-1}$ with a good linear relation coefficient of 0.922 in Fig. $3 b$.

However, by this approach, it is impossible to measure the decay rate of autotrophic bacteria owing to a low endogenous respiration rate for autotroph (normally from 1 to $3 \mathrm{mg} \mathrm{L} \mathrm{L}^{-1} \mathrm{~h}^{-1}$ ) and an extremely long experimental time. Indeed, Manser et al. (2006) conducted respirometric tests during 7 to 10 days to monitor the decrease of endogenous respiration rate of $\mathrm{AOB}$ and $\mathrm{NOB}$, and the values of $b_{\mathrm{AOB}}$ and $b_{\mathrm{NOB}}$ had no difference. In this study, default values of $b_{\mathrm{A}}$, $b_{\mathrm{AOB}}$, and $b_{\mathrm{NOB}}$ were adopted being $0.2,0.17$, and 0.17 , respectively, which have been used in other studies (Eldyasti et al. 2011; Henze et al. 1987).

Maximum growth rate of biomass is usually measured by a trend of gradual increase of exogenous respiration rate after substrate addition, which is indicated in Fig. 3c. Furthermore, Fig. $3 \mathrm{~d}$ suggests that the value of $\mu_{\text {max.H }}, \mu_{\text {max.AOB }}$, and $\mu$ max.NOB reached 3.06, 0.67, and 0.30 day $^{-1}$ for heterotroph, $A O B$, and $N O B$, respectively, by using Eq. 8. The premise of this approach can be concluded as excessive biofilm growth under a low ratio of biomass and substrate that corresponded to the ratio of volatile suspended sludge (VSS) by COD approximately being 1:4 (Kappeler and Gujer 1992). Thus, biomass growth is assumed to be associated with an exponential equation. For the biofilm, biomass concentration is quite larger than that of suspended sludge, so the substrate concentration should be enough high in order to produce a gradual increase of exogenous respiration rate. However, Fall et al. (2012) developed a new method to estimate $\mu_{\text {max.H }}$ by measuring the initial rates of respiration at different seeding levels of sludge even at high ratio of VSS/COD. But the batch

Table 1 Hydraulic parameters from hydraulic modeling in the hybrid bioreactor

\begin{tabular}{|c|c|c|c|c|c|c|c|c|c|c|}
\hline \multirow[t]{2}{*}{ Hydraulic saturation condition in aerobic part } & \multirow{2}{*}{$\begin{array}{l}V_{\text {void }} \\
\mathrm{L}\end{array}$} & \multirow{2}{*}{$\begin{array}{l}V_{\text {actual }} \\
\mathrm{L}\end{array}$} & \multicolumn{3}{|c|}{ Aerobic part } & \multirow[b]{2}{*}{$\mathrm{N}$} & \multicolumn{2}{|c|}{ Anoxic part } & \multirow{2}{*}{$\begin{array}{l}e_{\mathrm{v}} \\
\%\end{array}$} & \multirow[t]{2}{*}{$R$} \\
\hline & & & $\begin{array}{l}\mathrm{V}_{\text {plug }} \\
\mathrm{L}\end{array}$ & $\begin{array}{l}\mathrm{V}_{\mathrm{m}} \\
\mathrm{L}\end{array}$ & $\begin{array}{l}\mathrm{V}_{\mathrm{im}} \\
\mathrm{L}\end{array}$ & & $\begin{array}{l}\text { V } \\
\text { L }\end{array}$ & $\mathrm{N}$ & & \\
\hline Unsaturated & 5.00 & 1.49 & 0.23 & 0.85 & 0.09 & 1 & 0.32 & 1 & 30 & 91 \\
\hline Saturated & 5.00 & 2.25 & 0.68 & 0.96 & 0.29 & 2 & 0.32 & 1 & 45 & 83 \\
\hline
\end{tabular}


Fig. 3 Endogenous respiration rate (a) and calculating decay rate (b) of heterotroph; exogenous respiration rate (c) and calculating maximum growth rate $(\mathbf{d})$ of different bacteria: heterotroph (open diamonds), AOB (open squares), NOB (multiplication symbol)
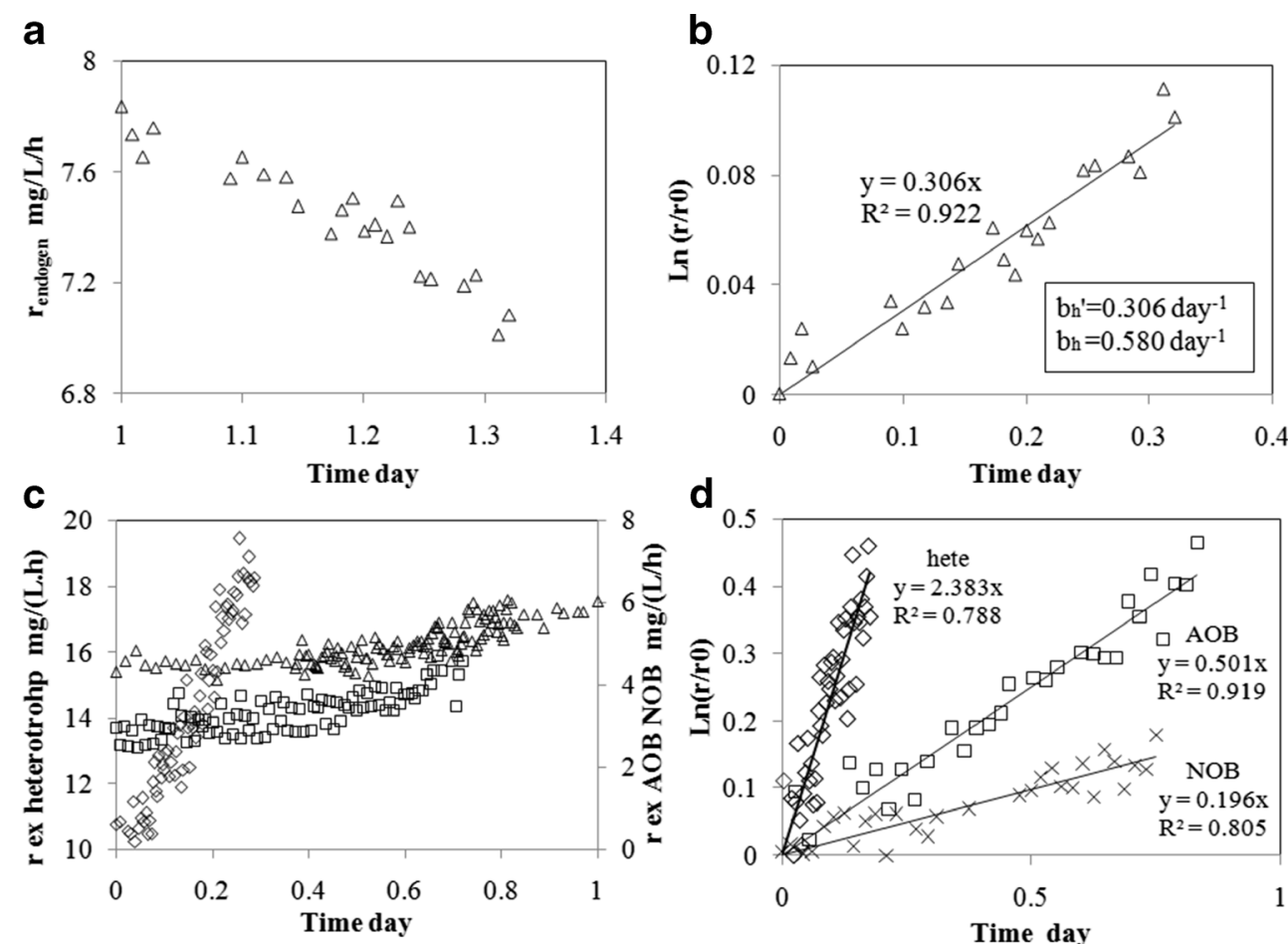

reactor in this novel method still needs to be improved owing to the complex operation of incremented biofilm seeding procedure.

Figure 4 shows the variation of respiration rate and $\mathrm{NH}_{4}{ }^{+}$ concentrations along the time, where the yield rate of $\mathrm{AOB}$ is calculated to be $0.30 \mathrm{~g} \mathrm{COD} / \mathrm{g} \mathrm{N}$ by analyzing the amount of removed $\mathrm{NH}_{4}{ }^{+}$and consumed oxygen at the end of test. Afterwards, yield rate was used to predict $\mathrm{NH}_{4}^{+}$concentration, which was compared with online measured $\mathrm{NH}_{4}{ }^{+}$concentrations to verify the precision of obtained yield rate. This fitting process is one of the major functions of online $\mathrm{NH}_{4}{ }^{+}$/ $\mathrm{NO}_{3}^{-}$measurement. A good consistency between experimental and fitted $\mathrm{NH}_{4}{ }^{+}$curves is clearly noticeable in Fig. 4. Additionally, supposing pollutant removal data are not available, it is wise to take advantage of yield rate to induce these data. Because yield rate is assumed to be relatively constant for a specific type of bacteria and is not quite sensitive to the environmental factors, even temperature (Tremier et al. 2005). Overall, calculating yield rate should be highlighted as a critical step for respirogram modeling.

\section{Modeling respirogram}

Variation of respiration rate after adding $\mathrm{NH}_{4} \mathrm{Cl}$, ATU, and sucrose is shown in Fig. 5. Simultaneously, removed $\mathrm{NH}_{4}{ }^{+}$ and accumulated $\mathrm{NO}_{3}{ }^{-}$were monitored online (Fig. 5a and b). Nearly equal values of consumed $\mathrm{NH}_{4}{ }^{+} \mathrm{N}$ and produced $\mathrm{NO}_{3}{ }^{-}-\mathrm{N}$ concentrations without obvious $\mathrm{NO}_{2}{ }^{-}$accumulation imply that there was two-step nitrification by $\mathrm{AOB}$ and $\mathrm{NOB}$ due to low $\mathrm{pH}$ of 6-7. High and low concentrations of injected $\mathrm{NH}_{4}{ }^{+}$were compared to verify the repeatability of the simulation of respirograms. Compared with low injected $\mathrm{NH}_{4}{ }^{+}-\mathrm{N}$ concentration of $3 \mathrm{mg} / \mathrm{L}$, high injected $\mathrm{NH}_{4}{ }^{+}-\mathrm{N}$ concentration

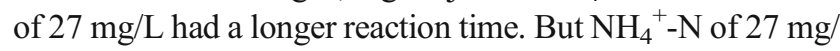
$\mathrm{L}$ was still relatively too low to realize a gradual increasing trend of exogenous respiration rate for biofilm. It is obvious that modeled respiration rate was in a good agreement with experimental one in both $\mathrm{NH}_{4}^{+}$loading rates. This fitting gives an opportunity to verify values of yield rate, maximum growth rate, and affinity constant for substrate that arrived at $0.30 \mathrm{~g} \mathrm{COD} \mathrm{g} \mathrm{N}^{-1}, 0.70 \mathrm{day}^{-1}$, and $2.40 \mathrm{mg} \mathrm{N} \mathrm{L}^{-1}$,

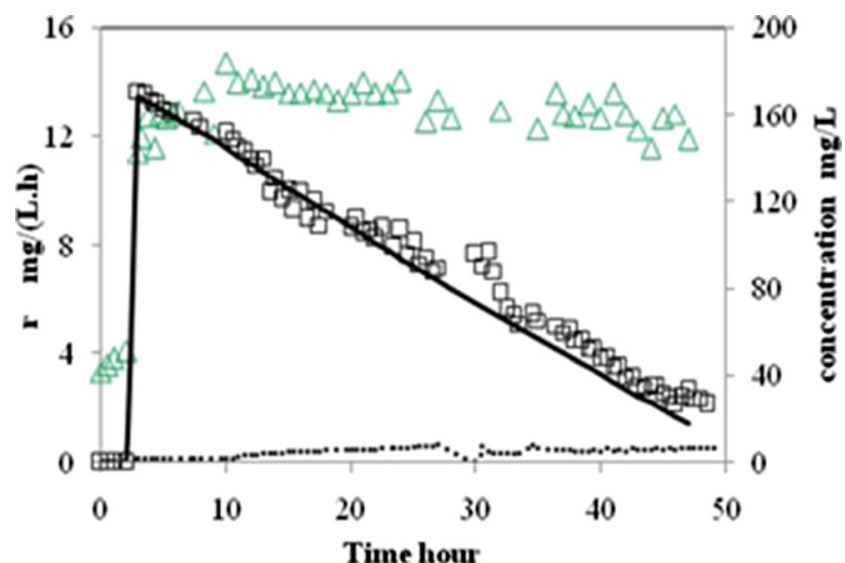

Fig. 4 Variations of respiration rate and $\mathrm{NH}_{4}{ }^{+}$concentration to calculate yield rate of $\mathrm{AOB}$ and fitting $\mathrm{NH}_{4}{ }^{+}$concentration by yield rate; respiration rate (open triangle), $\mathrm{NH}_{4}^{+}-\mathrm{N}$ (line) and $\mathrm{NO}_{3}^{-}{ }^{-} \mathrm{N}$ (broken line), predicted $\mathrm{NH}_{4}{ }^{+} \mathrm{N}$ (open squares) 
Fig. 5 Variations of respiration rate and concentrations of $\mathrm{NH}_{4}{ }^{+}$ and $\mathrm{NO}_{3}{ }^{-}$, for autotroph with heterotroph (a and $\mathbf{b}$ ), for AOB with heterotroph (c and d), for AOB followed by NOB (e); experimental respiration rate (open triangle), modeled respiration rate (dash-and-dotted line), $\mathrm{NH}_{4}{ }^{+}-\mathrm{N}($ line $), \mathrm{NO}_{3}{ }^{-}-\mathrm{N}$ (broken line)

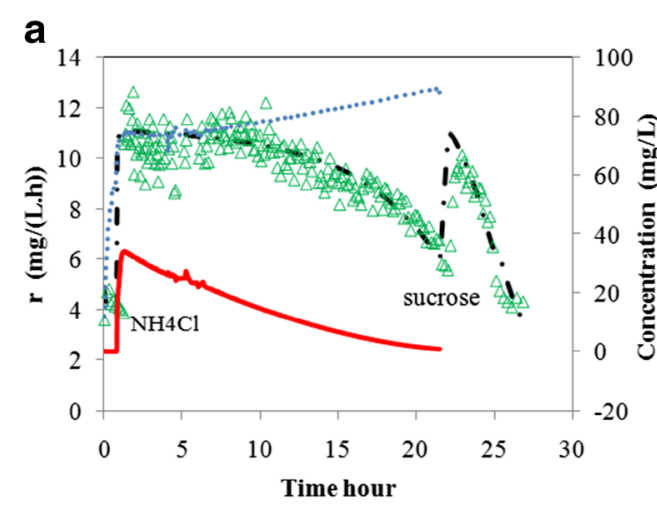

C
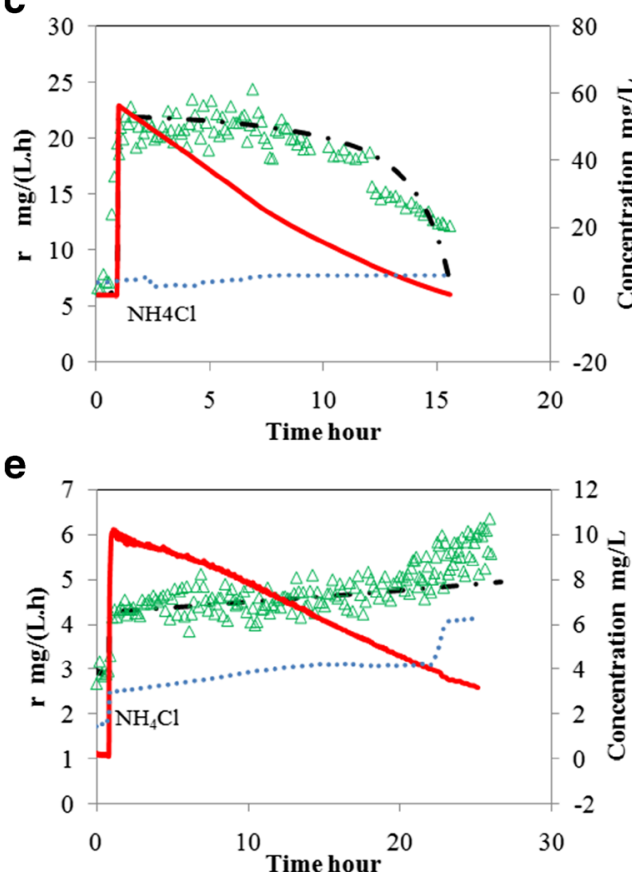

b

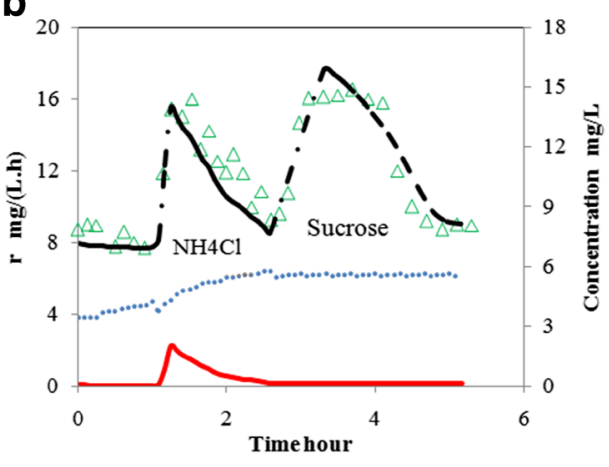

d

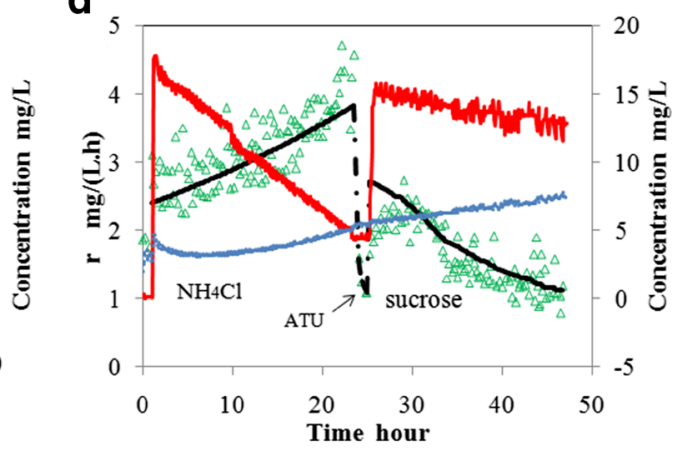

Table 2 Stoichiometries and biokinetics by modeling respirogram

\begin{tabular}{|c|c|c|c|c|c|c|c|c|}
\hline \multirow[t]{2}{*}{ Parameters } & \multirow[t]{2}{*}{ Symbols } & \multirow[t]{2}{*}{ Units } & \multicolumn{2}{|c|}{ Partial nitrification } & \multicolumn{2}{|c|}{$100 \%$ nitrification } & \multirow[t]{2}{*}{ Default values } & \multirow[t]{2}{*}{ Range of values } \\
\hline & & & $\mathrm{High}^{\mathrm{a}} \mathrm{NH}_{4}^{+}$ & Low ${ }^{\mathrm{b}} \mathrm{NH}_{4}^{+}$ & High $\mathrm{NH}_{4}^{+}$ & Low $\mathrm{NH}_{4}^{+}$ & & \\
\hline \multirow[t]{4}{*}{ Yield rate } & $Y_{\mathrm{A}}$ & g COD g N ${ }^{-1}$ & - & - & 0.31 & 0.30 & 0.24 & $0.07-0.28$ \\
\hline & $Y_{\mathrm{AOB}}$ & g_COD.g_N ${ }^{-1}$ & 0.30 & 0.28 & - & - & 0.15 & $0.10-0.21$ \\
\hline & $Y_{\mathrm{NOB}}$ & g_COD.g_N $\mathrm{N}^{-1}$ & 0.11 & 0.11 & - & - & 0.04 & $0.04-0.14$ \\
\hline & $Y_{\mathrm{H}}$ & g_COD.g_COD ${ }^{-1}$ & - & - & 0.51 & 0.52 & 0.67 & $0.09-0.75$ \\
\hline Decay rate & $b_{\mathrm{H}}$ & day $^{-1}$ & - & - & 0.58 & 0.58 & 0.62 & $0.02-1.60$ \\
\hline Maximum & $\mu_{\text {A.max }}$ & day $^{-1}$ & - & - & 0.70 & 0.70 & 1.00 & $0.04-1.00$ \\
\hline \multirow[t]{3}{*}{ Growth rate } & $\mu_{\mathrm{AOB} \text { max }}$ & day $^{-1}$ & 0.67 & 0.67 & - & - & 0.90 & $0.33-2.55$ \\
\hline & $\mu_{\text {NOB.max }}$ & day $^{-1}$ & 0.30 & 0.30 & - & - & 0.70 & $0.45-1.95$ \\
\hline & $\mu_{\mathrm{H} . \max }$ & day $^{-1}$ & - & - & 3.00 & 3.00 & 6.00 & $0.60-8.00$ \\
\hline Affinity & $K_{\mathrm{NH} . \mathrm{A}}$ & $\mathrm{mg} \mathrm{NH_{4 }}{ }^{+}-\mathrm{N} \cdot \mathrm{L}^{-1}$ & - & - & 2.40 & 2.40 & - & - \\
\hline \multirow[t]{2}{*}{ Constants } & $K_{\mathrm{NH} . \mathrm{AOB}}$ & $\mathrm{mg} \mathrm{NH}{ }_{4}^{+}-\mathrm{N} \cdot \mathrm{L}^{-1}$ & 2.40 & 2.40 & - & - & 0.70 & $0.02-17.50$ \\
\hline & $K_{\mathrm{S} . \mathrm{H}}$ & $\operatorname{mg}$ COD.L ${ }^{-1}$ & - & - & 25.00 & 25.00 & 15.00 & $5.00-225.00$ \\
\hline
\end{tabular}

${ }^{\text {a }}$ High influent $\mathrm{NH}_{4}^{+}$concentration

${ }^{\mathrm{b}}$ Low influent $\mathrm{NH}_{4}{ }^{+}$concentration 
Fig. 6 Experimental and modeled concentrations of $\mathrm{NH}_{4}^{+}$ and $\mathrm{NO}_{2}{ }^{-}$under different hydraulic saturation conditions; influent $\mathrm{NH}_{4}^{+}-\mathrm{N}$ (open diamonds), effluent $\mathrm{NH}_{4}{ }^{+}-\mathrm{N}$ (multiplication symbol), effluent $\mathrm{NO}_{2}^{-}-\mathrm{N}$ (open triangle), modeled curve (line)
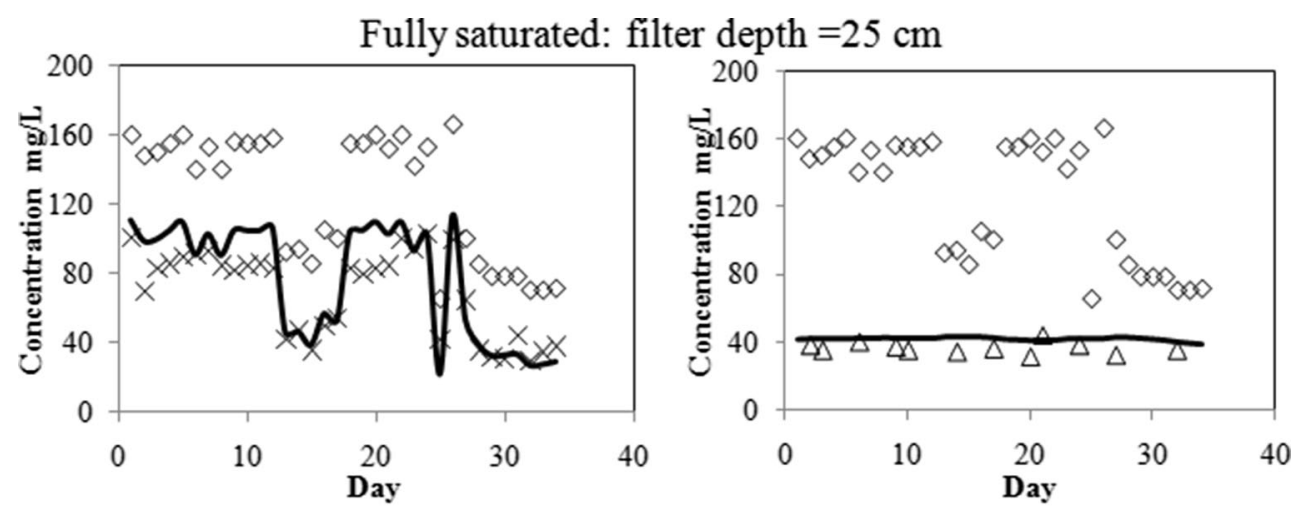

Half saturated: filter depth $=20 \mathrm{~cm}$
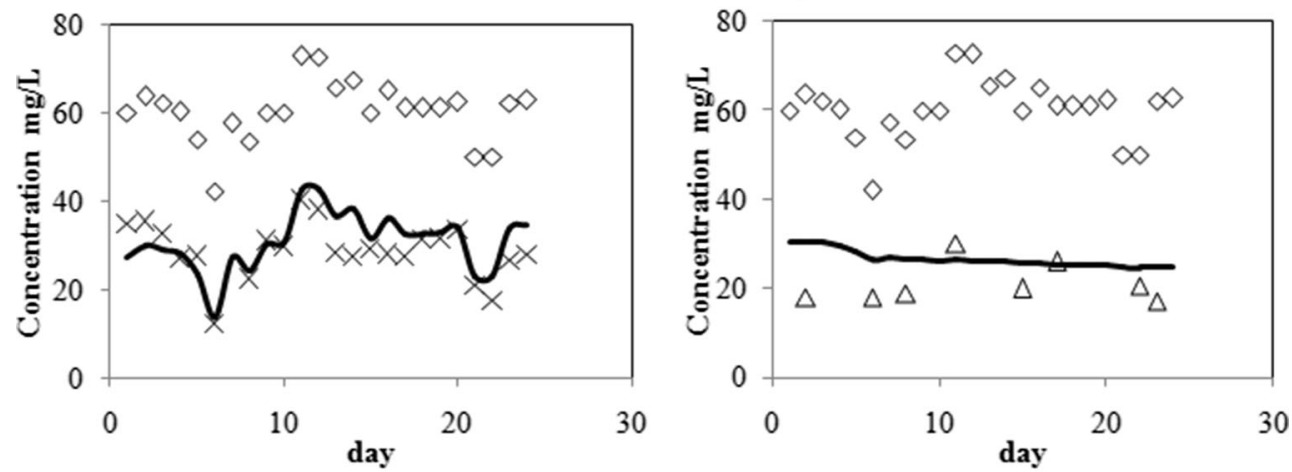

Unsaturated: filter depth $=15 \mathrm{~cm}$
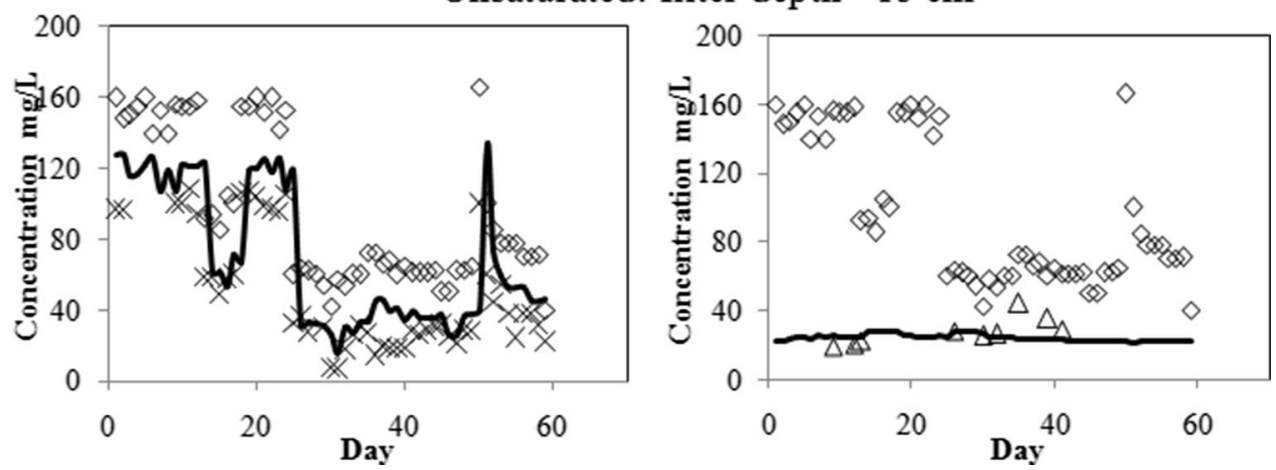

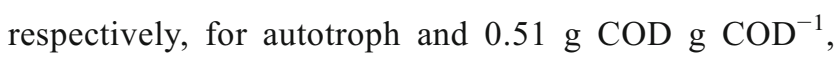
$3.00 \mathrm{day}^{-1}$, and $25.00 \mathrm{mg} \mathrm{COD} \mathrm{L}{ }^{-1}$, respectively, for heterotroph (Table 2).

Remarkable activity of AOB could be observed in Fig. $5 \mathrm{c}$ and $\mathrm{d}$, where no significant $\mathrm{NO}_{3}{ }^{-}$accumulation was monitored due to the high $\mathrm{pH}$ above 8.0. Because of the low biomass that can be induced from the low endogenous respiration rate in Fig. 5d, a significant gradual increasing trend of exogenous respiration rate appeared after injection of a low $\mathrm{NH}_{4}{ }^{+}-\mathrm{N}$ concentration of $15 \mathrm{mg} / \mathrm{L}$. Furthermore, the addition of ATU allowed endogenous respiration rate declining from 2 to $1 \mathrm{mg} \mathrm{L}^{-1} \mathrm{~h}^{-1}$. Therefore, numerical fitting gives values of $Y_{\mathrm{AOB}}, \mu_{\mathrm{AOB} . \max }$, and $K_{\mathrm{NH} . \mathrm{AOB}}$ being $0.29 \mathrm{~g} \mathrm{COD} \mathrm{g} \mathrm{N}^{-1}$, $0.67 \mathrm{day}^{-1}$, and $2.40 \mathrm{mg} \mathrm{N} \mathrm{L}^{-1}$, respectively, that remains similar at different injecting concentrations of $\mathrm{NH}_{4}{ }^{+}$(Table 2). The decrease of ammonium after addition of ATU in Fig. 5 is supposed to be caused by the assimilation of heterotrophy

Table 3 Values of three indicators to estimate the agreement between modeled and predicted data

\begin{tabular}{lllllllll}
\hline Saturation conditions & \multicolumn{3}{c}{ Effluent $\mathrm{NH}_{4}{ }^{+}$} & & & \multicolumn{2}{c}{ Effluent $\mathrm{NO}_{2}{ }^{-}$} & \\
\cline { 2 - 3 } \cline { 8 - 9 } & TIC & NOF & MIA & & TIC & NOF & MIA \\
\hline Fully saturated & 0.09 & 1.16 & 0.79 & & 0.08 & 0.63 & 0.26 \\
Half-saturated & 0.08 & 0.82 & 0.59 & & 0.15 & 0.94 & 0.55 \\
Unsaturated & 0.19 & 3.15 & 0.68 & & 0.16 & 0.90 & 0.30 \\
\hline
\end{tabular}




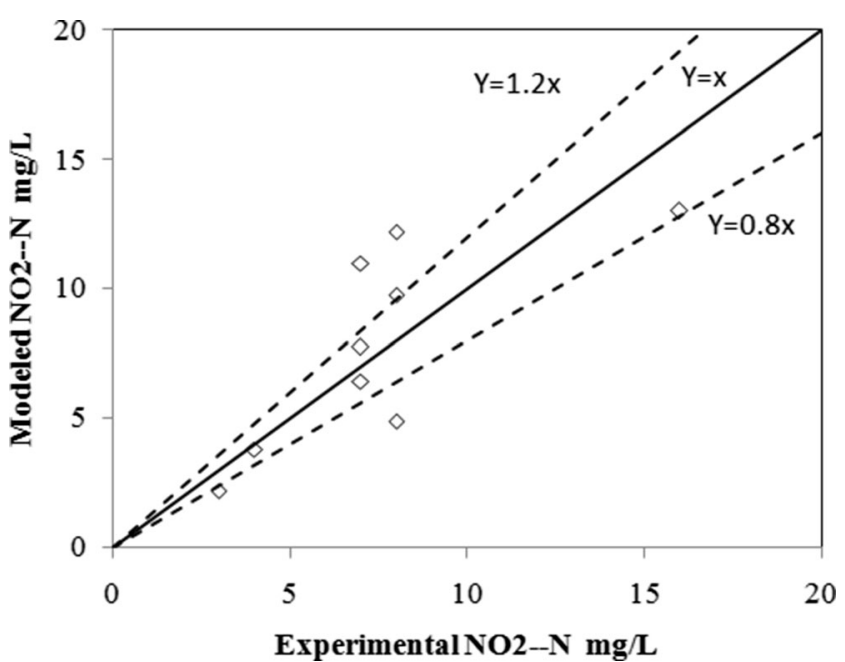

Fig. 7 Comparing experimental and modeled effluent $\mathrm{NO}_{2}^{-}-\mathrm{N}$ concentrations in anoxic part

(Akunna et al. 1994), while slight increase of nitrate during about $25 \mathrm{~h}$ could be caused by the aeration condition for a long time.

Interestingly, complete nitrification occurring after a certain time of partial nitrification was observed in Fig. 5e. After the injection of $\mathrm{NH}_{4} \mathrm{Cl}$, exogenous respiration rate increased to a stable value of $4.3 \mathrm{mg} \mathrm{L}^{-1} \mathrm{~h}^{-1}$ associated with the remarkable decrease of $\mathrm{NH}_{4}{ }^{+}$but slight $\mathrm{NO}_{3}{ }^{-}$increase, which indicates that partial nitrification was the dominant biological activity.
Nevertheless, remarkable $\mathrm{NO}_{3}{ }^{-} \mathrm{N}$ was detected arriving at $6 \mathrm{mg} \mathrm{L}^{-1}$ along with the gradual increase of exogenous respiration rate. This suggests that the activity of NOB contributed to the complete nitrification at the end of test. Wellfitted respiration rate gives the stoichiometry and kinetics of $\mathrm{AOB}$ and NOB in Table 2.

All simulated values in Table 2 remained in the range of reported values in other literatures (Eldyasti et al. 2011; Henze et al. 1987; Henze et al. 2000; Libelli et al. 2001). Additionally, the repeatability of calibrated stoichiometry and kinetics has been verified by changing the injected $\mathrm{NH}_{4}{ }^{+}$concentrations. Most of calibrated values are far from the default ones, which highlights the necessity of biological calibration.

\section{Modeling partial nitrification and denitrification}

Effluent $\mathrm{NO}_{2}{ }^{-}$and $\mathrm{NH}_{4}{ }^{+}$concentrations in the aerobic part of hybrid bioreactor were modeled in Fig. 6 under different hydraulic conditions that were mainly represented by the actual depth of filter bed. No obvious $\mathrm{NO}_{3}{ }^{-}$accumulation resulted from a high level of $\mathrm{pH}$ ranging from 8.0 to 8.5. For example, in the fully saturated hydraulic condition, the influent $\mathrm{NH}_{4}{ }^{+}-\mathrm{N}$ varied between 65 and $166 \mathrm{mg} \mathrm{L}^{-1}$, and the experimental effluent $\mathrm{NO}_{2}{ }^{-}-\mathrm{N}$ and $\mathrm{NH}_{4}{ }^{+}-\mathrm{N}$ concentrations varied from 31 to $44 \mathrm{mg} \mathrm{L}^{-1}$ and 30 to $103 \mathrm{mg} \mathrm{L}^{-1}$, respectively. Correspondingly, the modeled effluent $\mathrm{NO}_{2}{ }^{-} \mathrm{N}$ and $\mathrm{NH}_{4}{ }^{+}-\mathrm{N}$ concentrations varied from 38 to 43 and 22 to
Fig. 8 Predicted concentrations of pollutants in effluents as a function of three different operational factors; COD (line), $\mathrm{NH}_{4}{ }^{+}-\mathrm{N}$ (dash-and-dotted line), $\mathrm{NO}_{2}{ }^{-} \mathrm{N}$ (broken line)
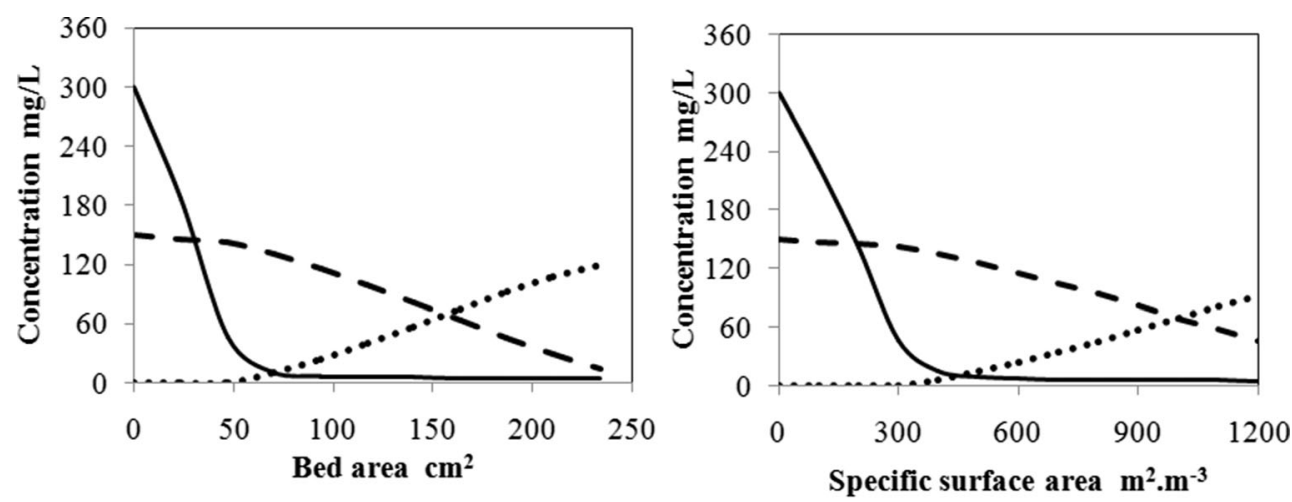
$114 \mathrm{mg} \mathrm{L}^{-1}$, respectively. In order to evaluate the agreement between the simulated effluent $\mathrm{NO}_{2}^{-}$and $\mathrm{NH}_{4}{ }^{+}$concentrations and experimental ones in all hydraulic saturation conditions, three indicators were proposed and summarized in Table 3. TIC remained below 0.3, although NOF for effluent $\mathrm{NH}_{4}{ }^{+}$modeling were over 1 in fully saturated and unsaturated conditions; MIA in both conditions were above 0.68 that, close to 1 . Generally, two indicators met the standard, so it is wise to adopt several indicators to evaluate the consistency.

Moreover, the importance of considering hydraulic saturation condition was highlighted by the model validation. Namely, compared with unsaturated and half-saturated conditions, the fully saturated condition contributed to the highest concentrations of produced $\mathrm{NO}_{2}^{-}$(around $40 \mathrm{mg} \mathrm{L}^{-1}$ ) due to the highest actual filter depth of $25 \mathrm{~cm}$. Afterwards, the produced $\mathrm{NO}_{2}{ }^{-}-\mathrm{N}$ decreased below $40 \mathrm{mg} \mathrm{L}^{-1}$ in the halfsaturated and unsaturated conditions with less filter depth. Supposedly the theoretical filter depth of $60 \mathrm{~cm}$ was used in the model, removed $\mathrm{NH}_{4}{ }^{+}$, and the produced $\mathrm{NO}_{2}{ }^{-}$will be overestimated.

The other phenomenon is the stable accumulated $\mathrm{NO}_{2}{ }^{-}$ concentration that is independent of the influent $\mathrm{NH}_{4}{ }^{+}$concentration. The reason could be the low constant affinity of $\mathrm{NH}_{4}{ }^{+}$-N being $2.4 \mathrm{mg} \mathrm{L}^{-1}$ in Table 2 that was quite lower than influent $\mathrm{NH}_{4}{ }^{+}-\mathrm{N}$ concentration. According to Monod equation, the nitrification rate had a weak relation to the substrate loading, giving rise to a stable $\mathrm{NO}_{2}^{-}$production rate. Nevertheless, $\mathrm{NH}_{4}{ }^{+}$removal changed along with the influent $\mathrm{NH}_{4}{ }^{+}$ concentrations, because a part of consumption resulting from $\mathrm{NH}_{4}{ }^{+}$assimilation by heterotroph for cell synthesis played a major role at high influent $\mathrm{NH}_{4}^{+}$concentrations. Similarly, Akunna et al. (1994) reported that up to $30 \%$ of added $\mathrm{NH}_{4}^{+}$ was used for both autotrophic and heterotrophic cell synthesis during aerobic organic carbon removal and nitrification.

When $\mathrm{NO}_{2}{ }^{-}$entered into anoxic part of hybrid bioreactor, it was denitrified by the heterotroph. The relative biokinetics involving in anoxic growth factor, maximum growth rate of heterotroph, and constant affinity of anoxic DO that were set as $0.8,5.0$ day $^{-1}$, and $0.45 \mathrm{mg} \mathrm{L}^{-1}$. According to the relation between experimental and predicted $\mathrm{NO}_{2}{ }^{-}-\mathrm{N}$ concentrations (Fig. 7), a good agreement was found for the majority of points corresponding to the confidence interval of $\pm 20 \%$. However, few points were out of this zone, which suggested the requirement of more experimental data, especially concentrations of $\mathrm{NO}_{2}{ }^{-}-\mathrm{N}$ larger than $10 \mathrm{mg} \mathrm{L}^{-1}$. While the concentration of $\mathrm{NO}_{2}^{-}$entering the anoxic part stayed low due to the dilution effect of inlet 2 (Fig. 1). Thus, it is wise to promote the partial nitrification in the aerobic part.

Alternatives to improve efficiency of partial nitrification

Taking advantage of another function of modeling to optimize the design and operational conditions of reactors for a better performance and less cost, we proposed a few possible alternatives to improve nitrification efficiency at high influent $\mathrm{NH}_{4}{ }^{+}$concentrations. Specifically, three factors including hydraulic loading rate (HLR), surface area of filter bed, and specific surface area of porous media were investigated in Fig. 8. Concerning predicted concentrations of $\mathrm{COD}, \mathrm{NH}_{4}^{+}$, and $\mathrm{NO}_{2}^{-}$, the HLR, bed surface area, and specific surface area of carrier were suggested to be $6 \mathrm{~L} \mathrm{day}^{-1}, 170 \mathrm{~cm}^{2}$, and $1,000 \mathrm{~m}^{2} \mathrm{~m}^{-3}$, respectively, for a desirable partial nitrification for the anammox process (ratio of $\mathrm{NH}_{4}{ }^{+}-\mathrm{N} / \mathrm{NO}_{2}{ }^{-} \mathrm{N}$ being $1: 1$ ) at high influent $\mathrm{NH}_{4}^{+}$concentration. On the contrary, once HLR increased up to $18 \mathrm{~L} \mathrm{day}^{-1}$ or bed surface area and specific surface area of carriers declined below $60 \mathrm{~cm}^{2}$ and $300 \mathrm{~m}^{2} \mathrm{~m}^{-3}$, respectively, no nitrification will even be monitored.

This result connects the numerical modeling with the engineering design that are two major areas in wastewater treatment. Many researchers gave efforts to apply models to guide engineering. A model of McCarty and Meyer (2005) indicates that particle size of carriers, reactor diameter, and pollutant concentration affected performance of biological fluidizedbed reactor, and the current design provide a good factor of safety in operation, even though empty-bed detention time decreased below $10 \mathrm{~min}$.

\section{Conclusion}

Model calibrations by hydraulic modeling and respirometric tests gave rise to good modeling results of partial nitrification coupled with denitrification in a hybrid biofilm reactor. Particularly, effluent $\mathrm{NH}_{4}{ }^{+}$and $\mathrm{NO}_{2}{ }^{-}$concentrations in reactors under different hydraulic saturation conditions were well predicted by the model due to calibrated actual hydraulic volumes and numbers of tanks. Most of biokinetics and stoichiometries could be calculated by the protocol in this study. Overall, the model developed in GPS-X software well predicts pollutant removal and helps engineers to optimize design and operation of reactors.

\section{References}

Akunna J, Bizeau C, Moletta R, Bernet N, Héduit A (1994) Combined organic carbon and complete nitrogen removal using anaerobic and aerobic upflow filters. Water Sci Technol 30:297-306

Eldyasti A, Andalib M, Hafez H, Nakhla G, Zhu J (2011) Comparative modeling of biological nutrient removal from landfill leachate using a circulating fluidized bed bioreactor (CFBBR). J Hazard Mater 187:140-149 
Fall C, Hooijmans C, Esparza-Soto M, Olguin M, Bâ K (2012) Initial-rate based method for estimating the maximum heterotrophic growth rate parameter $\left(\mu_{H \max }\right.$. Bioresour Technol 116:126-132

Gali A, Dosta J, Van Loosdrecht M, Mata-Alvarez J (2007) Two ways to achieve an anammox influent from real reject water treatment at labscale: partial SBR nitrification and SHARON process. Process Biochem 42:715-720

Gikas GD, Yiannakopoulou T, Tsihrintzis VA (2006) Modeling of nonpoint source pollution in a Mediterranean drainage basin. Environ Model Assess 11:219-233

Hellinga C, Van Loosdrecht M, Heijnen J (1999) Model based design of a novel process for nitrogen removal from concentrated flows. Math Comput Model Dyn Syst 5:351-371

Henze M, Grady C, Gujer W, Marais G, Matsuo T (1987) Activated sludge model No. 1. IAWPRC task group on mathematical modelling for design and operation of biological wastewater treatment, vol 1. Paper presented at the IAWPRC Scientific and Technical Reports, London

Henze M, Gujer W, van Mino T, Loosdrecht M (2000) Activated sludge models: ASM1, ASM2, ASM2d and ASM3. IWA, London

Huiliñir C, Romero R, Muñoz C, Bornhardt C, Roeckel M, Antileo C (2010) Dynamic modeling of partial nitrification in a rotating disk biofilm reactor: calibration, validation and simulation. Biochem Eng J 52:7-18

Hvala N, Strmčnik S, Šel D, Milanič S, Banko B (2005) Influence of model validation on proper selection of process models - an industrial case study. Comput Chem Eng 29:1507-1522

Kappeler J, Gujer W (1992) Estimation of kinetic parameters of heterotrophic biomass under aerobic conditions and characterization of wastewater for activated sludge modelling. Water Sci Technol 25:125-139

Legates DR, McCabe GJ (1999) Evaluating the use of "goodness-of-fit" measures in hydrologic and hydroclimatic model validation. Water Resour Res 35:233-241

Libelli SM, Ratini P, Spagni A, Bortone G (2001) Implementation, study and calibration of a modified ASM2d for the simulation of SBR processes. Water Sci Technol 43:69-76
Majewsky M, Gallé T, Bayerle M, Goel R, Fischer K, Vanrolleghem PA (2011) Xenobiotic removal efficiencies in wastewater treatment plants: residence time distributions as a guiding principle for sampling strategies. Water Res 45:6152-6162

Manser R, Gujer W, Siegrist H (2006) Decay processes of nitrifying bacteria in biological wastewater treatment systems. Water Res 40: 2416-2426

McCarty PL, Meyer TE (2005) Numerical model for biological fluidizedbed reactor treatment of perchlorate-contaminated groundwater. Environ Sci Technol 39:850-858

Petersen B, Vanrolleghem P, Gernaey K, Henze M (2002) Evaluation of an ASM1 model calibration procedure on a municipal-industrial wastewater treatment plant. J Hydroinf 4:15-38

Sánchez O, Michaud S, Escudié R, Delgenès J-P, Bernet N (2005) Liquid mixing and gas-liquid mass transfer in a three-phase inverse turbulent bed reactor. Chem Eng J 114:1-7

Séguret F, Racault Y, Sardin M (2000) Hydrodynamic behaviour of full scale trickling filters. Water Res 34:1551-1558

Torà JA, Moliné E, Carrera J, Pérez J (2013) Efficient and automated start-up of a pilot reactor for nitritation of reject water: from batch granulation to high rate continuous operation. Chem Eng J 226:319325

Tremier A, De Guardia A, Massiani C, Paul E, Martel J (2005) A respirometric method for characterising the organic composition and biodegradation kinetics and the temperature influence on the biodegradation kinetics, for a mixture of sludge and bulking agent to be co-composted. Bioresour Technol 96: 169-180

Vanrolleghem PA et al (2003) A comprehensive model calibration procedure for activated sludge models. Proc Water Environ Fed 2003: 210-237

Zeng M, Soric A, Roche N (2013) Calibration of hydrodynamic behavior and biokinetics for TOC removal modeling in biofilm reactors under different hydraulic conditions. Bioresour Technol 144:202-209 